Article

\title{
High Level Ethanol Production by Nitrogen and Osmoprotectant Supplementation under Very High Gravity Fermentation Conditions
}

\section{Pachaya Chan-u-tit ${ }^{1}$, Lakkana Laopaiboon ${ }^{2,3}$, Prasit Jaisil ${ }^{4}$ and Pattana Laopaiboon ${ }^{2,3, *}$}

1 Graduate School, Khon Kaen University, Khon Kaen 40002, Thailand;

E-Mail: japanese_cherry_16@hotmail.com

2 Department of Biotechnology, Faculty of Technology, Khon Kaen University, Khon Kaen 40002, Thailand; E-Mail: lakcha@kku.ac.th

3 Fermentation Research Center for Value Added Agricultural Products, Khon Kaen University, Khon Kaen 40002, Thailand

4 Department of Plant Science and Agricultural Resources, Faculty of Agriculture, Khon Kaen University, Khon Kaen 40002, Thailand; E-Mail: pjaisil@gmail.com

* Author to whom correspondence should be addressed; E-Mail: patlao@kku.ac.th; Tel./Fax: +66-4336-2121.

Received: 11 December 2012; in revised form: 19 January 2013 / Accepted: 4 February 2013 / Published: 8 February 2013

Abstract: Optimization of nutrient supplements i.e., yeast extract (1, 3 and $\left.5 \mathrm{~g} \cdot \mathrm{L}^{-1}\right)$, dried spent yeast (DSY: 4, 12 and $20 \mathrm{~g} \cdot \mathrm{L}^{-1}$ ) and osmoprotectant (glycine: 1,3 and $5 \mathrm{~g} \cdot \mathrm{L}^{-1}$ ) to improve the efficiency of ethanol production from a synthetic medium under very high gravity (VHG) fermentation by Saccharomyces cerevisiae NP 01 was performed using a statistical method, an $\mathrm{L}_{9}\left(3^{4}\right)$ orthogonal array design. The synthetic medium contained $280 \mathrm{~g} \cdot \mathrm{L}^{-1}$ of sucrose as a sole carbon source. When the fermentation was carried out at $30{ }^{\circ} \mathrm{C}$, the ethanol concentration $(P)$, yield $\left(Y_{p / s}\right)$ and productivity $\left(Q_{p}\right)$ without supplementation were $95.3 \mathrm{~g} \cdot \mathrm{L}^{-1}, 0.49 \mathrm{~g} \cdot \mathrm{g}^{-1}$ and $1.70 \mathrm{~g} \cdot \mathrm{L}^{-1} \cdot \mathrm{h}^{-1}$, respectively. According to the orthogonal results, the order of influence on the $P$ and $Q_{p}$ values were yeast extract $>$ glycine $>$ DSY, and the optimum nutrient concentrations were yeast extract, 3; DSY, 4 and glycine, $5 \mathrm{~g} \cdot \mathrm{L}^{-1}$, respectively. The verification experiment using these parameters found that the $P, Y_{p / s}$ and $Q_{p}$ values were $119.9 \mathrm{~g} \cdot \mathrm{L}^{-1}, 0.49 \mathrm{~g} \mathrm{~g}^{-1}$ and $2.14 \mathrm{~g} \cdot \mathrm{L}^{-1} \cdot \mathrm{h}^{-1}$, respectively. These values were not different from those of the synthetic medium supplemented with $9 \mathrm{~g} \cdot \mathrm{L}^{-1}$ of yeast extract, indicating that DSY could be used to replace some amount of yeast extract. When sweet sorghum juice cv. KKU40 containing $280 \mathrm{~g} \cdot \mathrm{L}^{-1}$ of total sugar 
supplemented with the three nutrients at the optimum concentrations was used as the ethanol production medium, the $P$ value $\left(120.0 \mathrm{~g} \cdot \mathrm{L}^{-1}\right)$ was not changed, but the $Q_{p}$ value was increased to $2.50 \mathrm{~g} \cdot \mathrm{L}^{-1} \cdot \mathrm{h}^{-1}$.

Keywords: bioethanol; nutrient supplements; orthogonal array design; osmoprotectant; very high gravity (VHG) fermentation; Saccharomyces cerevisiae

\section{Introduction}

The continuous use of fossil fuels to meet the World's energy demand causes an increase in carbon dioxide concentration in the atmosphere resulting in global warming. The combustion of fossil fuels is responsible for $73 \%$ of the carbon dioxide production [1]. Ethanol, an alternative to fossil fuel energy resources, has been a subject of great interest because the simple structure of its molecule makes it appropriate for spark ignition in internal combustion engines [2]. It is also an excellent fuel for future advanced flexi-fuel hybrid vehicles [3]. In addition, it is a renewable bio-based resource and can be produced from several different biomass feedstocks. To increase the productivity and cost effectiveness of ethanol production, many process improvements have been studied, including very high gravity (VHG) technology [4-7]. VHG fermentation technology is defined as the preparation and fermentation to completion of mashes containing 270 or more grams of dissolved solids per litre [8,9]. It has several advantages for industrial applications such as the increase in both ethanol concentration and fermentation rate by reducing the capital and the energy costs per litre of alcohol and the risk of bacterial contaminations [8,10-12].

However, the high sugar contents in the fermentation medium under VHG fermentation conditions causes an increase in osmotic pressure, which has a detrimental effect on yeast cells. Saccharomyces cerevisiae, the yeast commonly used for ethanol fermentations, can ferment increased amounts of sugars in the medium, when all required nutrients are provided in adequate amounts [13-16]. It was reported that under VHG conditions, yeast extract at $9 \mathrm{~g} \cdot \mathrm{L}^{-1}$ markedly stimulated the rates of fermentation and ethanol production [5,6,17-19]. However, yeast extract is relatively expensive, which makes it unsuitable for routine use in the industrial manufacture of ethanol. Suwanapong et al. [19] found that a low-cost by-product from brewer's industry, dried spent yeast (DSY) cells, could be used as a nitrogen source for VHG ethanol fermentation from sweet sorghum juice instead of yeast extract because it contained high nitrogen and many mineral salts. However, ethanol concentration and its productivity under DSY supplementation $\left(21 \mathrm{~g} \cdot \mathrm{L}^{-1}\right)$ were approximately $7 \%$ and $27 \%$ lower than those obtained under the yeast extract addition $\left(9 \mathrm{~g} \cdot \mathrm{L}^{-1}\right)$. Therefore, the use of the combination of DSY and yeast extract at a smaller amount may give high ethanol production efficiency comparable to that using $9 \mathrm{~g} \cdot \mathrm{L}^{-1}$ of yeast extract under VHG conditions.

Additionally, successful VHG fermentation is dependent on the yeast's ability to withstand the increase in osmotic stress and to tolerate high ethanol concentrations. Therefore, the supplementation with osmoprotectant in VHG media may increase cell survival under high ethanol production conditions. Thomas et al. [20] reported that glycine, known as a poor nitrogen source for growth, could serve directly or indirectly as an osmoprotectant and the addition of glycine stimulated yeast growth 
and fermentation. Apart from glycine, proline and glycine betaine were also used as osmoprotectants. However, it was reported that glycine was more effective as the osmoprotectant than either proline or glycine betaine [20].

Orthogonal array design (OAD), is believed to incorporate the advantages of the simplex method and factorial design [21,22]. The target of OAD is to select some special levels, while the selected combinations are the points that orthogonally distribute in the complete experiments. Under this condition, much fewer experiments are needed, and with parameter estimation, the best conditions can be determined [23].

The influence of the combination of yeast extract, DSY and glycine as the osmoprotectant to enhance fermentation efficiencies has rarely been reported, especially under VHG conditions. The aim of this study was to reduce the amount of yeast extract used as the nutrient supplement in a synthetic medium under VHG conditions for high level ethanol production. The three main parameters, namely yeast extract, DSY and glycine for high level ethanol production from the synthetic medium under VHG fermentation by $S$. cerevisiae NP 01 were optimized using an $\mathrm{L}_{9}\left(3^{4}\right)$ orthogonal array design. Ethanol production efficiencies from the synthetic medium supplemented with the three nutrients at the optimum concentrations were also compared to those supplemented with $9 \mathrm{~g} \cdot \mathrm{L}^{-1}$ of yeast extract. In addition, the ethanol production from sweet sorghum juice, a promising energy crop, under the nutrient supplementation conditions was also investigated.

\section{Experimental Section}

\subsection{Microorganism and Inoculum Preparation}

S. cerevisiae NP 01 isolated from Loog-pang (Chinese yeast cake) [17] was inoculated into $150 \mathrm{~mL}$ of yeast-malt extract (YM) medium (yeast extract, 3; malt extract, 3; peptone, 5 and glucose, $10 \mathrm{~g} \cdot \mathrm{L}^{-1}$ ) and incubated on a rotating shaker at $150 \mathrm{rpm}, 30{ }^{\circ} \mathrm{C}$ for $15 \mathrm{~h}$. To increase cell concentration and acclimatize cells to high sugar concentration, the yeast was then transferred into $360 \mathrm{~mL}$ of the YM medium containing $100 \mathrm{~g} \cdot \mathrm{L}^{-1}$ of sucrose and incubated under the same conditions. After $15 \mathrm{~h}$, the cells were harvested and used as an inoculum for ethanol fermentation.

\subsection{Raw Materials}

DSY obtained from Beerthip Brewery (1991) Co., Ltd., Bang Baan, Phra Nakhon Sri Ayutthaya, Thailand was kept at room temperature. Yeast extract and glycine were purchased from Himedia (Mumbai, India) and BDH (Poole dorset, England), respectively. Sweet sorghum juice (cv. KKU 40) extracted from its stems was obtained from the Department of Plant Science and Agricultural Resources, Faculty of Agriculture, Khon Kaen University, Thailand. To avoid storage problems and to prevent bacterial contamination, the juice which originally contained $18{ }^{\circ} \mathrm{Bx}$ of total soluble solids, was concentrated to $75^{\circ} \mathrm{Bx}$ and stored at $4{ }^{\circ} \mathrm{C}$ until use.

\subsection{Ethanol Production Medium and Nutrient Supplements}

The synthetic VHG medium modified from Melzock et al. [24] was used as the ethanol production (EP) medium. It contained $\mathrm{MgSO}_{4} \cdot 7 \mathrm{H}_{2} \mathrm{O}, 0.025 ; \mathrm{KH}_{2} \mathrm{PO}_{4}, 0.5 ; \mathrm{CaCl}_{2} \cdot 2 \mathrm{H}_{2} \mathrm{O}, 1.0 ;\left(\mathrm{NH}_{4}\right)_{2} \mathrm{SO}_{4}, 1.0$ and 
sucrose, $280 \mathrm{~g} \cdot \mathrm{L}^{-1}$. The EP medium was supplemented with yeast extract, DSY and glycine at different concentrations (Table 1). The EP medium without nutrient supplement and with $9 \mathrm{~g} \cdot \mathrm{L}^{-1}$ of yeast extract [5,6,19] was used for control experiments. The medium was transferred into a 500-mL air-locked Erlenmeyer flask with a final working volume of $400 \mathrm{~mL}$ and autoclaved at $110{ }^{\circ} \mathrm{C}$ for $28 \mathrm{~min}$ [18]. In the verification experiment, the ethanol production from the synthetic medium containing the optimum nutrient concentration was prepared in a $2-\mathrm{L}$ fermenter (Biostat ${ }^{\circledR} \mathrm{B}, \mathrm{B}$. Braun Biotech, Melsungen, Germany) with a $1-\mathrm{L}$ working volume and autoclaved at $110{ }^{\circ} \mathrm{C}$ for $40 \mathrm{~min}$. The concentrated sweet sorghum juice was diluted with distilled water to obtain $280 \mathrm{~g} \cdot \mathrm{L}^{-1}$ of total sugar. Then, the juice supplemented with and without yeast extract, DSY and glycine at the optimum concentrations were also used as the EP medium.

\subsection{Orthogonal Experiment Design of Nutrient Supplementation}

Based on many literature reviews $[5,6,13,19,25]$, the concentrations of yeast extract, DSY and glycine in the EP medium were varied as follows: yeast extract, 1 to $5 \mathrm{~g} \cdot \mathrm{L}^{-1}$; DSY, 4 to $20 \mathrm{~g} \cdot \mathrm{L}^{-1}$ and glycine 1 to $5 \mathrm{~g} \cdot \mathrm{L}^{-1}$ The $\mathrm{L}_{9}\left(3^{4}\right)$ orthogonal table was designed to examine the influence of the three main parameters, namely yeast extract $\left(A ; 1,3\right.$ and $\left.5 \mathrm{~g} \cdot \mathrm{L}^{-1}\right)$, DSY $\left(B ; 4,12\right.$ and $\left.20 \mathrm{~g} \cdot \mathrm{L}^{-1}\right)$ and glycine $\left(C ; 1,3\right.$ and $\left.5 \mathrm{~g} \cdot \mathrm{L}^{-1}\right)$ on ethanol fermentation. All experimental runs were performed in duplicate. The $\mathrm{L}_{9}\left(3^{4}\right)$ orthogonal test parameters are shown in Table 1 . The blank factor was a dummy and was used for error estimation. Analysis of variance (ANOVA) was used as the statistical analysis tool to estimate the effects of a factor on the characteristic properties [26].

Table 1. The $\mathrm{L}_{9}\left(3^{4}\right)$ orthogonal design for the ethanol fermentation.

\begin{tabular}{ccccc}
\hline Experimental run & $\boldsymbol{A}$ : Yeast extract $\left(\mathbf{g} \cdot \mathbf{L}^{-\mathbf{1}}\right)$ & $\left.\boldsymbol{B}: \mathbf{D S Y} \mathbf{a}^{\mathbf{a}} \mathbf{( g} \cdot \mathbf{L}^{\mathbf{- 1}}\right)$ & $\mathbf{B l a n k}$ & $\left.\boldsymbol{C}: \mathbf{G l y c i n e} \mathbf{( g} \cdot \mathbf{L}^{\mathbf{- 1}}\right)$ \\
\hline 1 & 1 & 4 & 1 & 1 \\
2 & 1 & 12 & 2 & 3 \\
3 & 1 & 20 & 3 & 5 \\
4 & 3 & 4 & 2 & 5 \\
5 & 3 & 12 & 3 & 1 \\
6 & 3 & 20 & 1 & 3 \\
7 & 5 & 4 & 3 & 3 \\
8 & 5 & 12 & 1 & 5 \\
9 & 5 & 20 & 2 & 1 \\
\hline
\end{tabular}

Note: ${ }^{\text {a }}$ dried spent yeast.

\subsection{Fermentation Conditions}

The ethanol fermentation under various conditions (Table 1) was carried out in the 500-mL air-locked Erlenmeyer flask at an initial yeast cell concentration in the EP medium of approximately $5 \times 10^{7}$ cells $\cdot \mathrm{mL}^{-1}$. The fermentation was performed in batch mode and the temperature was controlled at $30{ }^{\circ} \mathrm{C}$. The samples were collected at time intervals for analysis. To verify the reliability of the results from the orthogonal experiments, additional experiments under the optimum condition of the corresponding parameters and the control conditions with and without $9 \mathrm{~g} \cdot \mathrm{L}^{-1}$ of yeast extract were carried out in the 2-L fermenter. In addition, the sweet sorghum juice supplemented with yeast extract, 
DSY and glycine at the optimum concentrations was used as the EP medium for ethanol production in the 2-L fermenter.

\subsection{Analytical Methods}

Proximate chemical composition of yeast extract and DSY, i.e., total carbohydrate, protein, total fat, crude fiber, moisture and ash were determined by Central Laboratory (Thailand) Co., Ltd., Khon Kaen, Thailand, according to AOAC methods [27,28]. The minerals and trace elements (metal ions) were analyzed by atomic absorption spectrophotometry. The viable yeast cell numbers and total soluble solids in the fermentation broth were measured by direct counting method using haemacytometer with methylene blue staining technique and hand-held refractometer, respectively [29]. The fermentation broth was centrifuged at 10,000 rpm for $15 \mathrm{~min}$. The supernatant was then determined for residual total sugars by a phenol sulfuric acid method [30]. Ethanol concentration $\left(P, \mathrm{~g} \cdot \mathrm{L}^{-1}\right)$ was analyzed by gas chromatography (Shimadzu GC-14B, Tokyo, Japan, solid phase: polyethylene glycol (PEG-20M), carrier gas: nitrogen, $150{ }^{\circ} \mathrm{C}$ isothermal packed column, injection temperature $180{ }^{\circ} \mathrm{C}$, flame ionization detector temperature $250^{\circ} \mathrm{C}$; C-R7 Ae plus Chromatopac Data Processor) and 2-propanol was used as an internal standard [18]. The ethanol yield $\left(Y_{p / s}\right)$ and the volumetric ethanol productivity $\left(Q_{p}, \mathrm{~g} \cdot \mathrm{L}^{-1} \cdot \mathrm{h}^{-1}\right)$ were calculated [31]. Fermentable nitrogen or formol nitrogen in the fermentation broth was analyzed by the formol titration method [29]. Glycerol, the main by-product during ethanol fermentation, was quantified by HPLC equipped with a Shimadzu refractive index detector. The separation was performed in an Aminex $87 \mathrm{H}$ column at $40{ }^{\circ} \mathrm{C}$ with $5 \mathrm{mM} \mathrm{H}_{2} \mathrm{SO}_{4}$ as eluent at a flow rate of $0.6 \mathrm{~mL} \cdot \mathrm{min}^{-1}[32]$.

\section{Results and Discussion}

\subsection{Proximate Chemical Composition of Yeast Extract and DSY}

The compositions of yeast extract and DSY are shown in Table 2. Total carbohydrate in DSY was about four fold that in yeast extract, while the protein content in the DSY was only $67 \%$ of that in yeast extract. Total fat and crude fiber contents in yeast extract were lower than those in DSY. The ash content in yeast extract was approximately two fold that in DSY. Mineral and trace elements required for yeast growth and/or ethanol production [33] were also detected in yeast extract and DSY as shown in Table 2.

The protein content of DSY in this study was about $8 \%$ higher than that $(41.75 \%)$ reported by Suwanapong et al. [19] indicating that the composition of the company-supplied DSY varied slightly from lot to lot. According to the protein content of yeast extract and DSY and data from many literature reports $[5,6,13,19,25]$, the concentrations of yeast extract, DSY and glycine in the $\mathrm{L}_{9}\left(3^{4}\right)$ orthogonal experiments for the ethanol fermentation were selected as previously mentioned.

\subsection{The Orthogonal Experiment Results of Ethanol Fermentation}

Batch ethanol fermentation of the experimental runs 1 to 9 (Table 1) was carried out. The results of the fermentation of Run 1 (yeast extract, 1; DSY, 4 and glycine $1 \mathrm{~g} \cdot \mathrm{L}^{-1}$ ) are shown in Figure 1. 
Table 2. The compositions of yeast extract (Himedia, India) and DSY (Beerthip Brewery (1991) Co., Ltd., Thailand).

\begin{tabular}{ccc}
\hline Constituents & Yeast extract & DSY $^{\mathbf{a}}$ \\
\hline Total carbohydrate (\%) & 8.98 & 35.88 \\
Protein (\%) & 74.50 & 50.12 \\
Total fat (\%) & 0.07 & 2.53 \\
Crude fiber (\%) & $\mathrm{ND}^{\mathrm{b}}$ & 0.13 \\
Moisture (\%) & 5.19 & 5.29 \\
Ash (\%) & 11.26 & 6.18 \\
\hline Mineral and trace elements & & \\
$\mathrm{P}\left(\mathrm{g} \mathrm{kg}^{-1}\right)$ & 10.96 & 13.13 \\
$\mathrm{~K}\left(\mathrm{~g} \mathrm{~kg}^{-1}\right)$ & 60.67 & 18.28 \\
$\mathrm{Na}\left(\mathrm{g} \mathrm{kg}^{-1}\right)$ & 8.20 & 3.40 \\
$\mathrm{~S}\left(\mathrm{~g} \mathrm{~kg}^{-1}\right)$ & 3.50 & 3.50 \\
$\mathrm{Ca}\left(\mathrm{g} \mathrm{kg}^{-1}\right)$ & 0.25 & 1.58 \\
$\mathrm{Mg}\left(\mathrm{mg} \mathrm{kg}^{-1}\right)$ & 247.00 & 4.17 \\
$\mathrm{Fe}\left(\mathrm{mg} \mathrm{kg}^{-1}\right)$ & 59.39 & 65.11 \\
$\mathrm{Mn}\left(\mathrm{mg} \mathrm{kg}^{-1}\right)$ & 1.35 & 2.02 \\
$\mathrm{Cu}\left(\mathrm{mg} \mathrm{kg}^{-1}\right)$ & 1.47 & 3.58 \\
$\mathrm{Zn}\left(\mathrm{mg} \mathrm{kg}^{-1}\right)$ & 68.26 & 48.90 \\
$\mathrm{Ni}\left(\mathrm{mg} \mathrm{kg}^{-1}\right)$ & 0.52 & 0.54 \\
$\mathrm{Mo}\left(\mathrm{mg} \mathrm{kg}^{-1}\right)$ & 0.06 & 4.78 \\
\hline
\end{tabular}

Note: ${ }^{\mathrm{a}}$ dried spent yeast and ${ }^{\mathrm{b}}$ not detected.

Figure 1. Batch ethanol fermentation of Run 1 from the synthetic medium containing $280 \mathrm{~g} \cdot \mathrm{L}^{-1}$ of total sugar supplemented with yeast extract, 1 ; DSY, 4 and glycine, $1 \mathrm{~g} \cdot \mathrm{L}^{-1}$ : log viable cells $(\boldsymbol{\bullet}), \mathrm{pH}(\bullet)$, total sugar $(\bullet)$ and ethanol $(\boldsymbol{\Delta})$.

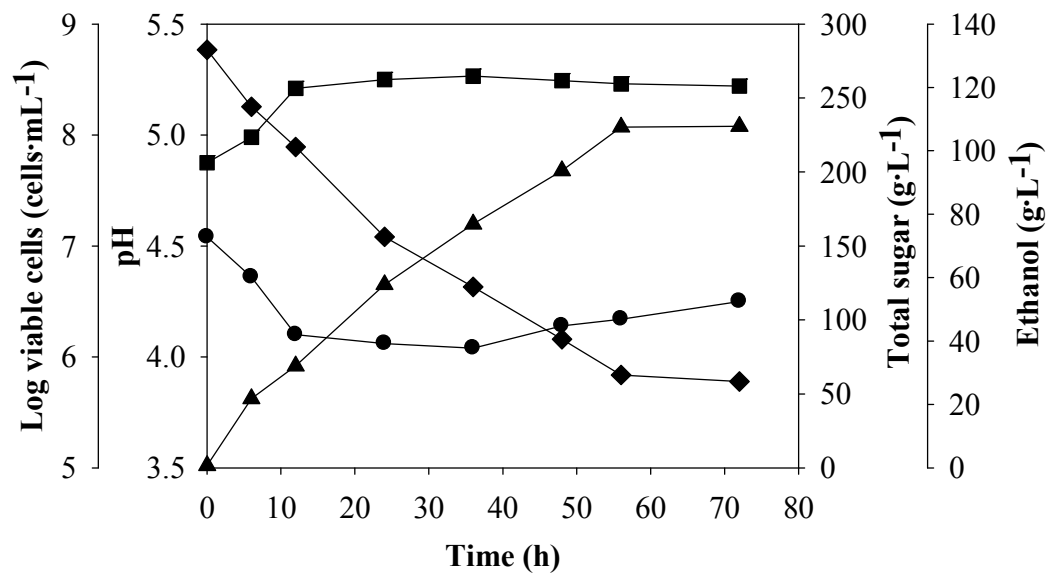

At the beginning of the fermentation, the initial cell and total sugar concentrations were $5.7 \times 10^{7}$ cells $\cdot \mathrm{mL}^{-1}$ and $282.5 \mathrm{~g} \cdot \mathrm{L}^{-1}$, respectively. No lag phase was observed after inoculation. The yeast cell numbers increased significantly in the first $12 \mathrm{~h}$, to a value of $2.6 \times 10^{8}$ cells $\cdot \mathrm{mL}^{-1}$ and rarely changed afterwards. The $\mathrm{pH}$ of the fermentation broth decreased from 4.5 to 4.1 at $12 \mathrm{~h}$, and increased slightly to 4.3 at the end of the fermentation. 
The sugar was not completely consumed under this condition, with $62.8 \mathrm{~g} \cdot \mathrm{L}^{-1}$ of total sugar remaining in the broth. The $P$ value increased with increasing fermentation time, and the highest value was $107.5 \mathrm{~g} \cdot \mathrm{L}^{-1}$ at $56 \mathrm{~h}$, corresponding to $Q_{p}, Y_{p / s}$ and sugar consumption of $1.92 \mathrm{~g} \cdot \mathrm{L}^{-1} \cdot \mathrm{h}^{-1}, 0.47 \mathrm{~g} \cdot \mathrm{g}^{-1}$ and $79.2 \%$, respectively. The profiles of the parameters measured during the batch ethanol fermentation of the eight remaining experimental runs were similar to those of Run 1 (data not shown). Table 3 shows the orthogonal experiment results of the viable yeast cell concentration, $P, Q_{p}, Y_{p / s}$ and sugar consumption at the fermentation time of $56 \mathrm{~h}$. The initial cell concentration under all conditions ranged from 5.6 to $5.7 \times 10^{7}$ cells $\cdot \mathrm{mL}^{-1}$. At $56 \mathrm{~h}$ fermentation time, the viable yeast cell concentrations were similar, with a range of 2.5 to $2.8 \times 10^{8}$ cells $\cdot \mathrm{mL}^{-1}$, indicating that the nutrients in the synthetic medium (Section 2.3) were sufficient for yeast growth. However, the different amounts of nutrient supplements affected the ethanol fermentation efficiencies and sugar consumption. The highest $P, Q_{p}$, $Y_{p / s}$ and sugar consumption were obtained from Run 4 . In contrast, the lowest $P$ and sugar consumption were obtained from Run 9, which contained the highest concentrations of yeast extract $\left(5 \mathrm{~g} \cdot \mathrm{L}^{-1}\right)$ and DSY $\left(20 \mathrm{~g} \cdot \mathrm{L}^{-1}\right)$ with low glycine $\left(1 \mathrm{~g} \cdot \mathrm{L}^{-1}\right)$. Similar results were reported by Nofemele et al. [34] who found that although the growth of $S$. cerevisiae in sugarcane molasses medium containing 0.5 to $4.0 \mathrm{~g} \cdot \mathrm{L}^{-1}$ of urea at $35^{\circ} \mathrm{C}$ were not different, the supplementation with urea at $2.0 \mathrm{~g} \cdot \mathrm{L}^{-1}$ gave the maximum ethanol concentration and fermentation efficiency. Decreased ethanol fermentation efficiency was observed at higher urea concentrations $\left(3.0\right.$ and $\left.4.0 \mathrm{~g} \cdot \mathrm{L}^{-1}\right)$.

Table 3. Orthogonal experiment results of ethanol fermentation from the synthetic medium containing $280 \mathrm{~g} \cdot \mathrm{L}^{-1}$ of total sugar at the fermentation time of $56 \mathrm{~h}$.

\begin{tabular}{|c|c|c|c|c|c|}
\hline \multirow[b]{2}{*}{$\begin{array}{l}\text { Experimental } \\
\text { run }^{a}\end{array}$} & \multicolumn{5}{|c|}{ Mean (range) } \\
\hline & $\begin{array}{l}\text { Viable yeast cells } \\
\quad\left(\text { cells } \cdot \mathrm{mL}^{-1}\right)\end{array}$ & $\begin{array}{c}P \\
\left(\mathrm{~g} \cdot \mathrm{L}^{-1}\right)\end{array}$ & $\begin{array}{c}Q_{p} \\
\left(\mathrm{~g} \cdot \mathrm{L}^{-1} \cdot \mathbf{h}^{-1}\right)\end{array}$ & $\begin{array}{c}Y_{p / s} \\
\left(g^{-} \cdot g^{-1}\right)\end{array}$ & $\begin{array}{c}\text { Sugar consumption } \\
(\%)\end{array}$ \\
\hline R1 & $2.8 \times 10^{8}\left(1.5 \times 10^{6}\right)^{\mathrm{e}}$ & $107.5(1.4)^{\mathrm{b}, \mathrm{c}}$ & $1.92(0.02)^{b, c}$ & $0.47(0.02)^{\mathrm{b}, \mathrm{c}}$ & $79.2(1.2)^{\mathrm{b}, \mathrm{c}}$ \\
\hline R2 & $2.8 \times 10^{8}\left(2.0 \times 10^{6}\right)^{\mathrm{e}}$ & $106.0(2.3)^{\mathrm{b}}$ & $1.89(0.04)^{\mathrm{b}}$ & $0.47(0.00)^{\mathrm{b}, \mathrm{c}}$ & $77.9(1.1)^{\mathrm{b}}$ \\
\hline R3 & $2.6 \times 10^{8}\left(1.2 \times 10^{6}\right)^{\mathrm{c}}$ & $108.7(1.8)^{\mathrm{b}, \mathrm{c}}$ & $1.94(0.04)^{\mathrm{c}}$ & $0.46(0.02)^{\mathrm{b}, \mathrm{c}}$ & $80.1(1.1)^{b, c, d}$ \\
\hline R4 & $2.8 \times 10^{8}\left(1.1 \times 10^{6}\right)^{\mathrm{e}}$ & $119.3(1.5)^{\mathrm{f}}$ & $2.13(0.02)^{f}$ & $0.49(0.02)^{\mathrm{c}}$ & $85.2(1.2)^{\mathrm{e}}$ \\
\hline R5 & $2.5 \times 10^{8}\left(1.3 \times 10^{6}\right)^{b}$ & $113.8(2.4)^{\mathrm{e}}$ & $2.03(0.02)^{\mathrm{e}}$ & $0.45(0.02)^{\mathrm{b}}$ & $83.4(1.2)^{\mathrm{d}, \mathrm{e}}$ \\
\hline R6 & $2.6 \times 10^{8}\left(2.0 \times 10^{6}\right)^{\mathrm{c}}$ & $112.1(0.3)^{\mathrm{d}, \mathrm{e}}$ & $2.00(0.02)^{\mathrm{d}, \mathrm{e}}$ & $0.46(0.00)^{b, c}$ & $83.1(1.0)^{\mathrm{d}, \mathrm{e}}$ \\
\hline R7 & $2.8 \times 10^{8}\left(1.5 \times 10^{6}\right)^{\mathrm{e}}$ & $110.0(0.2)^{\mathrm{c}, \mathrm{d}}$ & $1.96(0.00)^{\mathrm{c}, \mathrm{d}}$ & $0.47(0.02)^{\mathrm{b}, \mathrm{c}}$ & $82.2(1.1)^{\mathrm{c}, \mathrm{d}, \mathrm{e}}$ \\
\hline $\mathrm{R} 8$ & $2.7 \times 10^{8}\left(1.4 \times 10^{6}\right)^{d}$ & $112.0(1.9)^{\mathrm{d}, \mathrm{e}}$ & $2.00(0.04)^{\mathrm{d}, \mathrm{e}}$ & $0.45(0.04)^{b}$ & $83.4(1.1)^{\mathrm{d}, \mathrm{e}}$ \\
\hline R9 & $2.6 \times 10^{8}\left(1.9 \times 10^{6}\right)^{\mathrm{c}}$ & $105.9(0.8)^{\mathrm{b}}$ & $1.89(0.02)^{b}$ & $0.45(0.00)^{b}$ & $77.5(1.1)^{b}$ \\
\hline
\end{tabular}

Notes: ${ }^{\text {a }}$ see Table $1 ; P=$ ethanol concentration, $Q_{p}=$ ethanol productivity and $Y_{p / s}=$ ethanol yield. The experiments were performed in duplicate and the results were expressed as mean with the range in parenthesis; ${ }^{\mathrm{b}, \mathrm{c}, \mathrm{d}, \mathrm{e}, \mathrm{f}, \mathrm{g}}$ Means followed by the same letter within the same column are not significantly different using Duncan's multiple range test at the level of 0.05 .

In the industry, high $P$ and $Q_{p}$ values have been continuously pursued because of the energy savings in the downstream distillation and waste distillate treatment. Thus, the $P$ and $Q_{p}$ values are considered in this study to judge the ethanol production. 


\subsection{Impact of Factors on Ethanol Concentration and Volumetric Ethanol Productivity}

The $P$ values of the orthogonal experiments (Table 3) ranged from 105.9 to $119.3 \mathrm{~g} \cdot \mathrm{L}^{-1}$. Range analysis was applied to clarify the important sequence of yeast extract (factor $A$ ), DSY (factor $B$ ) and glycine (factor $C$ ) concentrations in the orthogonal experiments (Table 4). The highest range value $(R)$ of 7.68 was found for factor $A$, while the lowest range value of 3.38 was found for factor $B$. The bigger $R$ value of a factor represents a greater effect on the final $P$ value. According to the range, the order of influence on the $P$ value was yeast extract $>$ glycine $>$ DSY. Thus, the optimum condition for improving $P$ value was determined as $A_{2} B_{1} C_{3}$ corresponding to yeast extract, 3; DSY, 4 and glycine, $5 \mathrm{~g} \cdot \mathrm{L}^{-1}$. The analysis of variance (ANOVA) method was used to confirm the order of the effects of these three parameters on the final $P$ value. The model $F$-value of 184.14 implied that the model was significant. There was only a $5.00 \%$ chance that "a model $F$-value" this large could occur due to noise. Values of probe $F<0.05$ indicated that the model terms were significant. According to the $F$ value, the order of influence $\left(F_{\text {yeast extract }}=360.68, F_{\text {glycine }}=127.19\right.$ and $\left.F_{D S Y}=64.55\right)$ was similar to that of the $R$ value. The effect of the dummy variable was calculated in the same manner as the effects of the experimental variables. If the effect shown by a dummy variable is 0 , there is no interaction and no error in measuring the response. If not, it is assumed to be a measure of the lack of experimental precision plus any analytical error in measuring the response [35]. The correlation between predicted and actual results of the $P$ values had $R^{2}$ of $99.8 \%$. These results confirmed an acceptable fit of the model to the data [36].

Table 4. The range analysis of $\mathrm{L}_{9}\left(3^{4}\right)$ orthogonal experiment for ethanol concentration $(P)$ and productivity $\left(Q_{p}\right)$.

\begin{tabular}{ccccccccc}
\hline & \multicolumn{2}{c}{$\boldsymbol{A}$ : Yeast extract } & \multicolumn{2}{c}{$\boldsymbol{B}_{\mathbf{~} \mathbf{\text { DSY}}} \mathbf{a}$} & \multicolumn{2}{c}{ blank } & \multicolumn{2}{c}{$\boldsymbol{C}$ : Glycine } \\
\cline { 2 - 9 } & $P$ & $Q_{P}$ & $P$ & $Q_{P}$ & $P$ & $Q_{P}$ & $P$ & $Q_{P}$ \\
\hline$K_{1}$ & 644.3 & 11.50 & 673.6 & 12.02 & 663.1 & 13.81 & 654.4 & 11.68 \\
$K_{2}$ & 690.3 & 12.32 & 663.6 & 11.84 & 662.4 & 13.84 & 656.1 & 11.70 \\
$K_{3}$ & 655.8 & 11.70 & 653.3 & 11.66 & 664.9 & 13.79 & 679.9 & 12.14 \\
$k_{1}$ & 107.4 & 1.92 & 112.3 & 2.00 & 110.5 & 2.30 & 109.1 & 1.94 \\
$k_{2}$ & 115.1 & 2.05 & 110.6 & 1.97 & 110.4 & 2.31 & 109.4 & 1.95 \\
$k_{3}$ & 109.3 & 1.95 & 108.9 & 1.94 & 110.8 & 2.30 & 113.3 & 2.02 \\
$R$ & 7.68 & 0.13 & 3.38 & 0.06 & 0.30 & 0.01 & 4.24 & 0.08 \\
$Q$ & $A_{2}$ & $A_{2}$ & $B_{1}$ & $B_{1}$ & & & $C_{3}$ & $C_{3}$ \\
\hline
\end{tabular}

Note: ${ }^{\text {a }}$ dried spent yeast.

Figure 2 shows the $P$ values at different levels and factors. The $P$ values ranged from $107.4\left(k_{1}\right)$ to $115.1\left(k_{2}\right) \mathrm{g} \cdot \mathrm{L}^{-1}$; when the yeast extract concentration was increased from 1 to $3 \mathrm{~g} \cdot \mathrm{L}^{-1}$ (Table 4 ). The highest $P$ value $\left(115.1 \mathrm{~g} \cdot \mathrm{L}^{-1}, k_{2}\right)$ was achieved at $3 \mathrm{~g} \cdot \mathrm{L}^{-1}$ of yeast extract. This implied that both permeation intensity of nutrients from the fermentation broth to the inside of yeast cells and the ethanol from the inside of yeast cells to the broth could be improved [13,20], in other words, the sugar uptake and ethanol production were enhanced by increasing the yeast extract concentration from 1 to $3 \mathrm{~g} \cdot \mathrm{L}^{-1}$. However, higher yeast extract concentrations $\left(>3 \mathrm{~g} \cdot \mathrm{L}^{-1}\right)$ did not increase the $P$ value. For the DSY concentrations, $S$. cerevisiae NP 01 showed the highest $P$ value of $112.3 \mathrm{~g} \cdot \mathrm{L}^{-1}\left(k_{1}\right)$ at the DSY 
concentration of $4 \mathrm{~g} \cdot \mathrm{L}^{-1}$. Increasing in the DSY concentration in the medium did not promote ethanol production. Bafrncová et al. [13] reported that excess assimilable nitrogen did not lead to an increase in the ethanol production rate and a reduction of the fermentation time. The higher the glycine concentration was, the more ethanol production was obtained. The maximum $P$ value of $113.3 \mathrm{~g} \cdot \mathrm{L}^{-1}$ $\left(k_{3}\right)$ was obtained at the glycine concentration of $5 \mathrm{~g} \cdot \mathrm{L}^{-1}$. The value was higher than that reported by Thomas et al. [20], who found that the addition of $3 \mathrm{~g} \cdot \mathrm{L}^{-1}$ of glycine into VHG ethanolic fermentation medium containing $350 \mathrm{~g} \cdot \mathrm{L}^{-1}$ of sugar improved sugar consumption of $S$. cerevisiae NCYC 1324 from $173 \mathrm{~g} \cdot \mathrm{L}^{-1}$ (no addition) to $324 \mathrm{~g} \cdot \mathrm{L}^{-1}$, and the cell viability increased from $13 \%$ to $78 \%$.

Figure 2. The ethanol concentrations at different levels and factors: yeast extract $(\bullet)$, dried spent yeast (DSY, $\mathbf{})$ and glycine $(\diamond)$.

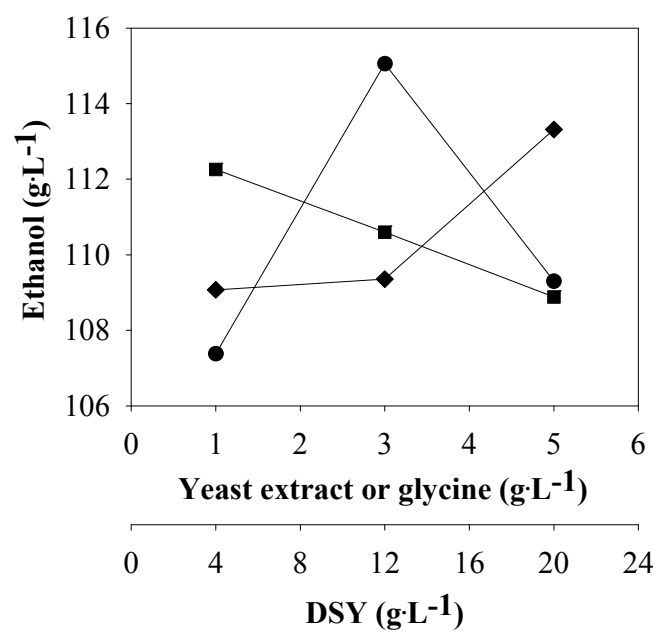

Regarding the ethanol productivity or $Q_{p}$, the values varied among the combined factor treatments of the orthogonal experiments in the range of 1.89 to $2.13 \mathrm{~g} \cdot \mathrm{L}^{-1} \cdot \mathrm{h}^{-1}$ (Table 3). Table 4 shows the range analysis of $\mathrm{L}_{9}\left(3^{4}\right)$ orthogonal experiments of the $Q_{p}$ values. The range $(R)$ of factors $A, C$ and $B$ was $0.13,0.08$ and 0.06 , respectively. The bigger $R$ value of a factor represents the greater effect on the final $Q_{p}$. Thus, the order of influence on the $Q_{p}$ value was yeast extract $>$ glycine $>$ DSY, which was the same as that for the $P$ value. The optimum condition for improving $Q_{p}$ value $\left(A_{2} B_{1} C_{3}\right)$ was also not different from that for the $P$ value. Thus, the optimum fermentation condition was determined as follows: yeast extract, 3; DSY, 4 and glycine, $5 \mathrm{~g} \cdot \mathrm{L}^{-1}$. The order of influence on $P$ and $Q_{p}$ values was not always consistent as reported by Liu and Shen [37]. According to the $F$ value in our study, the order of influence for $Q_{p}$ value $\left(F_{\text {yeast extract }}=457.00, F_{\text {glycine }}=169.00\right.$ and $\left.F_{D S Y}=81.00\right)$ was similar to that of the $R$ value. The correlation between the predicted and actual results of the $Q_{p}$ values having $R^{2}$ of $99.9 \%$, which was higher than $75 \%$, confirming that the fitted model to the results was acceptable [36]. The profiles of the $Q_{p}$ values under different conditions were similar to those of the $P$ values shown in Figure 2. The highest $Q_{p}$ of $2.05 \mathrm{~g} \cdot \mathrm{L}^{-1} \cdot \mathrm{h}^{-1}\left(k_{2}\right)$ was found at $3 \mathrm{~g} \cdot \mathrm{L}^{-1}$ of yeast extract. This implied that the fermentation rate would be enhanced with the increased yeast extract concentration from 1 to $3 \mathrm{~g} \cdot \mathrm{L}^{-1}$ and decreased with the increased yeast extract concentration from 3 to $5 \mathrm{~g} \cdot \mathrm{L}^{-1}$. The highest $Q_{p}$ value of $2.00 \mathrm{~g} \cdot \mathrm{L}^{-1} \cdot \mathrm{h}^{-1}\left(k_{1}\right)$ was obtained at $4 \mathrm{~g} \cdot \mathrm{L}^{-1}$ of DSY. A trend of lower $Q_{p}$ value with an increase in the DSY concentration was observed. The maximum $Q_{p}$ value was 
$2.02 \mathrm{~g} \cdot \mathrm{L}^{-1} \cdot \mathrm{h}^{-1}\left(k_{3}\right)$ at $5 \mathrm{~g} \cdot \mathrm{L}^{-1}$ of glycine. This might be explained by the fact that the $Q_{p}$ value would be boosted with the increased glycine concentration.

\subsection{The Verification Experiments}

In order to verify the reliability of the results in flasks, an additional experiment with the corresponding parameters under the optimum nutrient condition $A_{2} B_{1} C_{3}$ (yeast extract, 3; DSY, 4 and glycine, $5 \mathrm{~g} \cdot \mathrm{L}^{-1}$ ) was carried out in the 2-L fermenter (Figure 3 ).

Figure 3. Batch ethanol fermentation in the 2-L fermenter from the synthetic medium containing $280 \mathrm{~g} \cdot \mathrm{L}^{-1}$ of total sugar and nutrient supplements at the optimum nutrient concentrations (yeast extract, 3; DSY, 4 and glycine, $5 \mathrm{~g} \cdot \mathrm{L}^{-1}$ ) (closed symbols, solid lines), without nutrients supplement (open symbols, solid lines), with $9 \mathrm{~g} \cdot \mathrm{L}^{-1}$ of yeast extract (open symbols, dashed lines) and with $13.4 \mathrm{~g} \cdot \mathrm{L}^{-1}$ of DSY (closed symbols, dashed lines).

(a) $\mathrm{pH}(\bullet \circ)$ and log viable cells $(\bullet \square)$ and $(\mathbf{b})$ total sugar $(\bullet)$ and ethanol $(\Delta \Delta)$.

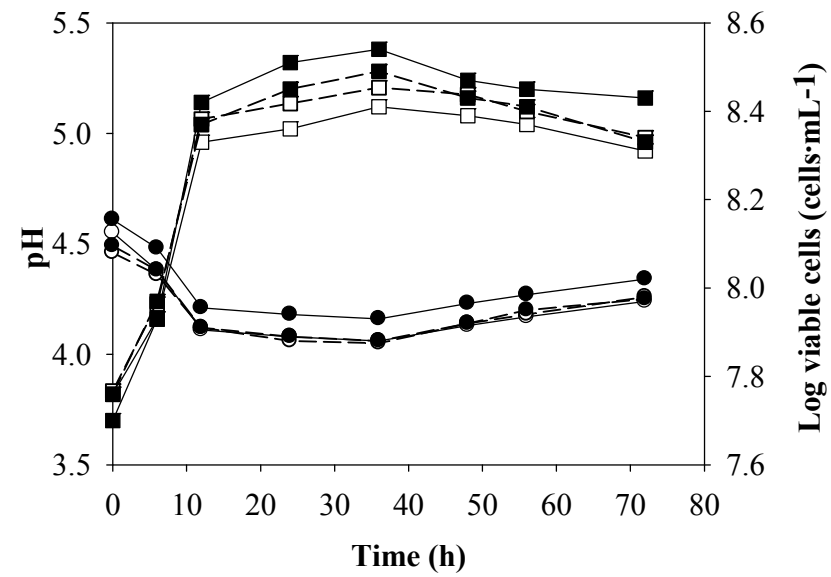

(a)

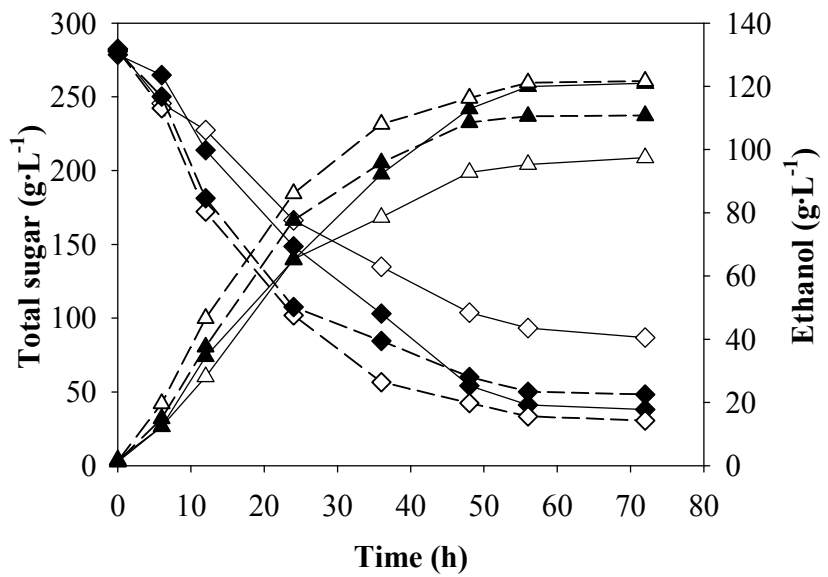

(b)

The viable yeast cells increased from $5.7 \times 10^{7}$ to $3.5 \times 10^{8}$ cells $\cdot \mathrm{mL}^{-1}$ before a slight decrease after $36 \mathrm{~h}$, while $\mathrm{pH}$ fell from approximately 4.5 to 4.1 in the first $12 \mathrm{~h}$ of the fermentation after which time an increase to approximately 4.3 was observed. The viable cell numbers and total sugar remaining in the broth were $2.7 \times 10^{8}$ cells $\cdot \mathrm{mL}^{-1}$ and $41.1 \mathrm{~g} \cdot \mathrm{L}^{-1}$, respectively; corresponding to a sugar consumption of $85.2 \%$. The sugar and ethanol concentrations were almost constant at $56 \mathrm{~h}$ with the $P, Q_{p}$ and $Y_{p / s}$ values of $119.9 \mathrm{~g} \cdot \mathrm{L}^{-1}, 2.14 \mathrm{~g} \cdot \mathrm{L}^{-1} \cdot \mathrm{h}^{-1}$ and 0.49 , respectively (Table 5). The control experiment operating under the same condition without nutrient supplement was also performed (Figure 3 ). The $P$, $Q_{p}$ and $Y_{p / s}$ values of the control treatment were $95.3 \mathrm{~g} \cdot \mathrm{L}^{-1}, 1.70 \mathrm{~g} \cdot \mathrm{L}^{-1} \cdot \mathrm{h}^{-1}$ and $0.49 \mathrm{~g} \cdot \mathrm{g}^{-1}$, respectively at the fermentation time of $56 \mathrm{~h}$ (Table 5). The viable yeast cells and ethanol concentration under the optimum condition were approximately 28 and $26 \%$ higher than those of the control treatment, respectively. This clearly indicated that the use of both nitrogen supplements coupled with the osmoprotectant significantly promoted ethanol production from the synthetic medium under the VHG conditions. When the synthetic medium was supplemented with $9 \mathrm{~g} \cdot \mathrm{L}^{-1}$ of yeast extract and used as the EP medium, the changes of $\mathrm{pH}$ in the broth were comparable with those under the optimum nutrient condition (Figure 3), but the viable cell concentrations under the optimum nutrient supplementation 
were slightly higher. This might be due to the positive effect of the osmoprotectant addition on cell growth as reported by Thomas et al. [20]. The sugar consumption and the ethanol production rates in the first $48 \mathrm{~h}$ under the yeast extract addition were higher, implying that some essential trace elements in yeast extract (Table 2) promoted those rates. When the synthetic medium was supplemented with $13.4 \mathrm{~g} \cdot \mathrm{L}^{-1}$ of DSY (total nitrogen content was equal to that of $9 \mathrm{~g} \cdot \mathrm{L}^{-1}$ of yeast extract), the changes of $\mathrm{pH}$ and viable yeast cells in the broth and glycerol production were similar to those under the yeast extract supplementation (Figure 3 and Table 5). However, the ethanol production efficiencies were lower. This implied that the fermentation activities of the yeast were different under both conditions. The $P, Q_{p}, Y_{p / s}$ values and glycerol production at $56 \mathrm{~h}$ under the yeast extract addition and optimum nutrient conditions were similar (Table 5). These indicated that DSY and glycine could be used to replace some amount of yeast extract for high level ethanol production under VHG fermentation.

Our results demonstrated that the optimum condition $A_{2} B_{1} C_{3}$ was suitable and reliable for VHG ethanol fermentation by $S$. cerevisiae NP 01. Similar results were observed by Bafrncová et al. [13] who reported that the supplementation with yeast extract, 12; cell walls, 3; glycine, 3 and soya flour, $20 \mathrm{~g} \cdot \mathrm{L}^{-1}$ into synthetic medium containing $300 \mathrm{~g} \cdot \mathrm{L}^{-1}$ of glucose led to an increase in ethanol production efficiency with the $P$ and $Q_{p}$ values of $91 \mathrm{~g} \cdot \mathrm{L}^{-1}$ and $3.30 \mathrm{~g} \cdot \mathrm{L}^{-1} \cdot \mathrm{h}^{-1}$, respectively.

Table 5. Fermentation parameters of batch ethanol production under VHG fermentation at $280 \mathrm{~g} \cdot \mathrm{L}^{-1}$ of total sugar.

\begin{tabular}{|c|c|c|c|c|c|c|c|}
\hline \multirow{2}{*}{ Supplement } & \multicolumn{6}{|c|}{ Mean (range) } & \multirow{2}{*}{$t$ (h) } \\
\hline & Medium & $P\left(\mathrm{~g} \cdot \mathrm{L}^{-1}\right)$ & $Q_{p}\left(\mathrm{~g} \cdot \mathrm{L}^{-1} \cdot \mathrm{h}^{-1}\right)$ & $Y_{p / s}\left({\left.\mathrm{~g} \cdot \mathrm{g}^{-1}\right)}\right.$ & Glycerol $\left(\mathrm{g} \cdot \mathrm{L}^{-1}\right)$ & SC (\%) & \\
\hline None & Synthetic & $95.3(0.4)^{\mathrm{d}}$ & $1.70(0.00)^{\mathrm{d}}$ & $0.49(0.00)^{\mathrm{c}}$ & $12.47(0.4)^{\mathrm{c}}$ & $67.0(3.5)^{\mathrm{c}}$ & 56 \\
\hline Yeast extract $\left(9 \mathrm{~g} \cdot \mathrm{L}^{-1}\right)$ & Synthetic & $121.1(0.5)^{\mathrm{e}}$ & $2.16(0.00)^{\mathrm{e}}$ & $0.49(0.00)^{\mathrm{c}}$ & $12.36(0.2)^{\mathrm{c}}$ & $88.2(2.1)^{\mathrm{f}}$ & 56 \\
\hline $\operatorname{DSY}^{\mathrm{a}}\left(13.4 \mathrm{~g} \cdot \mathrm{L}^{-1}\right)$ & Synthetic & $110.5(0.2)^{\mathrm{f}}$ & $1.97(0.01)^{\mathrm{d}}$ & $0.48(0.01)^{\mathrm{d}}$ & $12.55(0.3)^{\mathrm{c}}$ & $82.2(1.0)^{\mathrm{d}}$ & 56 \\
\hline Optimum $\left(A_{2} B_{1} C_{3}\right)$ & Synthetic & $119.9(0.3)^{\mathrm{e}}$ & $2.14(0.02)^{\mathrm{f}}$ & $0.49(0.00)^{\mathrm{c}}$ & $11.34(0.7)^{\mathrm{d}}$ & $85.2(2.3)^{\mathrm{e}}$ & 56 \\
\hline None & $\mathrm{SSJ}^{\mathrm{b}}$ & $90.7(0.2)^{\mathrm{c}}$ & $1.62(0.01)^{\mathrm{c}}$ & $0.49(0.01)^{\mathrm{c}}$ & $11.77(0.2)^{\mathrm{d}}$ & $65.8(1.1)^{\mathrm{c}}$ & 56 \\
\hline Optimum $\left(A_{2} B_{1} C_{3}\right)$ & SSJ & $120.1(0.3)^{\mathrm{e}}$ & $2.50(0.00)^{g}$ & $0.48(0.00)^{\mathrm{d}}$ & $10.75(0.4)^{\mathrm{e}}$ & $93.1(3.9)^{\mathrm{g}}$ & 48 \\
\hline
\end{tabular}

Notes: ${ }^{\mathrm{a}}$ dried spent yeast; ${ }^{\mathrm{b}}$ sweet sorghum juice; $P=$ ethanol concentration, $Q_{p}=$ ethanol productivity, $Y_{p / s}=$ ethanol yield, $\mathrm{SC}=$ sugar consumption and $t=$ fermentation time. The experiments were performed in duplicate and the results were expressed as mean with the range in parenthesis; ${ }^{\text {c,d,e,f,g }}$ Means followed by the same letter within the same column are not significantly different using Duncan's multiple range test at the level of 0.05 .

Since the amount of assimilable nitrogen affected the ethanol production efficiency, especially under the VHG ethanol fermentation conditions [12,13,38], the fermentable nitrogen concentrations in the fermented broth were determined. Table 6 shows the fermentable nitrogen utilized by $S$. cerevisiae NP 01 during the ethanol fermentation from the synthetic medium in the orthogonal experiments compared to those of the medium with and without $9 \mathrm{~g} \cdot \mathrm{L}^{-1}$ of yeast extract. In the orthogonal experiments, it seemed that the utilization of fermentable nitrogen in the medium increased when the $P$ values increased. According to Table 2, the initial total nitrogen in the broth of Run 2 was equal to that in the broth containing $9 \mathrm{~g} \cdot \mathrm{L}^{-1}$ of yeast extract, but the fermentable nitrogen in the former was only $56 \%$ of that in the latter. Therefore, the initial fermentable nitrogen concentrations of the nine experimental runs were much lower than that of the yeast extract supplementation. However, it seemed 
that the amount of nitrogen consumption did not always relate to ethanol production performance of the yeast as reported by many groups $[13,31,38-40]$. The $P$ values of the medium containing $9 \mathrm{~g} \cdot \mathrm{L}^{-1}$ of yeast extract $\left(121.1 \mathrm{~g} \cdot \mathrm{L}^{-1}\right)$ and R4 $\left(119.3 \mathrm{~g} \cdot \mathrm{L}^{-1}\right)$ were similar, but the utilized fermentable nitrogen of the former $\left(317.5 \mathrm{mg} \cdot \mathrm{L}^{-1}\right)$ was much higher than that of the latter $\left(250.3 \mathrm{mg} \cdot \mathrm{L}^{-1}\right)$. The results also showed that the fermentable nitrogen was not limited, even in the medium without nutrient supplementation, because the fermentable nitrogen still remained at approximately $110 \mathrm{mg} \cdot \mathrm{L}^{-1}$. This suggested that the mineral and trace elements in yeast extract and DSY (Table 2) might affect the capability of nitrogen utilization by the yeast under VHG conditions.

Table 6. Fermentable nitrogen during ethanol production from the synthetic medium under various nutrient supplements by $S$. cerevisiae NP 01.

\begin{tabular}{|c|c|c|c|}
\hline \multirow{3}{*}{ Condition } & \multicolumn{3}{|c|}{ Mean (range) } \\
\hline & \multicolumn{2}{|c|}{ Fermentable nitrogen ${ }^{a}\left(\mathrm{mg} \cdot \mathrm{L}^{-1}\right)$} & \multirow{2}{*}{$\begin{array}{c}\text { Ethanol concentration } \\
\left(g \cdot L^{-1}\right)\end{array}$} \\
\hline & Initial & Utilized & \\
\hline No supplement & $291.3(1.5)^{c}$ & $182.0(4.0)^{\mathrm{c}}$ & $95.3(0.4)^{\mathrm{c}}$ \\
\hline Yeast extract $\left(9 \mathrm{~g} \cdot \mathrm{L}^{-1}\right)$ & $628.8(2.3)^{1}$ & $317.5(3.8)^{\mathrm{j}}$ & $121.1(0.5)^{\mathrm{j}}$ \\
\hline $\mathrm{R} 1$ & $330.3(4.8)^{\mathrm{d}}$ & $209.1(5.7)^{\mathrm{e}}$ & $107.5(1.4)^{\mathrm{b}, \mathrm{c}}$ \\
\hline $\mathrm{R} 2$ & $349.2(3.2)^{\mathrm{e}}$ & $205.9(2.3)^{\mathrm{e}}$ & $106.0(2.3)^{\mathrm{b}}$ \\
\hline R3 & $465.3(2.0)^{\mathrm{k}}$ & $216.9(3.7)^{\mathrm{f}}$ & $108.7(1.8)^{\mathrm{b}, \mathrm{c}}$ \\
\hline R4 & $351.4(1.0)^{\mathrm{e}}$ & $250.3(2.6)^{\mathrm{i}}$ & $119.3(1.5)^{\mathrm{f}}$ \\
\hline R5 & $372.2(4.0)^{f}$ & $239.7(4.7)^{\mathrm{h}}$ & $113.8(2.4)^{\mathrm{e}}$ \\
\hline R6 & $482.4(1.8)^{\mathrm{j}}$ & $235.0(3.0)^{\mathrm{g}}$ & $112.1(0.3)^{\mathrm{d}, \mathrm{e}}$ \\
\hline R7 & $382.8(2.1)^{\mathrm{g}}$ & $219.7(4.1)^{\mathrm{f}}$ & $110.0(0.2)^{\mathrm{c}, \mathrm{d}}$ \\
\hline $\mathrm{R} 8$ & $390.3(2.5)^{\mathrm{h}}$ & $241.2(4.4)^{\mathrm{h}}$ & $112.0(1.9)^{\mathrm{d}, \mathrm{e}}$ \\
\hline R9 & $489.2(2.1)^{\mathrm{i}}$ & $200.0(3.0)^{d}$ & $105.9(0.8)^{\mathrm{b}}$ \\
\hline
\end{tabular}

Notes: ${ }^{a}$ At the end of the experiment $(72 \mathrm{~h}) ;{ }^{\mathrm{b}}$ At the fermentation time of $56 \mathrm{~h}$; The experiments were performed in duplicate and the results were expressed as mean with the range in parenthesis; c,d,e,f,g,h,i,j,k, Means followed by the same letter within the same column are not significantly different using Duncan's multiple range test at the level of 0.05 .

\subsection{VHG Ethanol Fermentation from Sweet Sorghum Juice}

Sweet sorghum [Sorghum bicolor (L.) Moench] is an attractive alternative feedstock for the future supplies of bioethanol because its stalks contain high concentrations of fermentable sugar, and it can be cultivated in nearly all temperatures and tropical climate areas [41-43]. In this study, the ethanol production from the sweet sorghum juice $\left(280 \mathrm{~g} \cdot \mathrm{L}^{-1}\right.$ of total sugar) supplemented with yeast extract, 3 ; DSY, 4; and glycine, $5 \mathrm{~g} \cdot \mathrm{L}^{-1}$ was carried out in the 2-L fermenter to compare the ethanol fermentation efficiencies with those from the synthetic medium. The viable cell numbers and total sugar remaining in the broth were $2.3 \times 10^{8}$ cells $\cdot \mathrm{mL}^{-1}$ and $18.6 \mathrm{~g} \cdot \mathrm{L}^{-1}$, respectively (Figure 4 ). All parameters measured were almost constant at $48 \mathrm{~h}$ with the $P, 120.1 \mathrm{~g} \cdot \mathrm{L}^{-1} ; Q_{p}, 2.50 \mathrm{~g} \cdot \mathrm{L}^{-1} \cdot \mathrm{h}^{-1} ; Y_{p / s}, 0.48$ and sugar consumption, 93.1\% (Table 5). Under the optimum supplementation, the changes of viable cell concentration during fermentation in the juice and the synthetic medium were similar. However, the $Q_{p}$ value of the sweet sorghum juice was higher than that of the synthetic medium, implying that some elements, e.g., metal ions and vitamins in the juice [18,33], might play an important role in stimulating 
the fermentation rate in terms of sugar consumption and ethanol production under VHG conditions. The $P$ values from the sweet sorghum juice containing $9 \mathrm{~g} \cdot \mathrm{L}^{-1}$ of yeast extract reported by Nuanpeng et al. [5] and Khongsay et al. [6] were 120.2 and $119.4 \mathrm{~g} \cdot \mathrm{L}^{-1}$, respectively. These values were not different from the $P$ value $\left(120.1 \mathrm{~g} \cdot \mathrm{L}^{-1}\right)$ obtained in this study under the optimum nutrient supplementation $\left(A_{2} B_{1} C_{3}\right)$, but the amount of yeast extract added in this study was reduced three fold. This also indicated that DSY, a low-cost nitrogen source, could be used to replace some amount of yeast extract and the addition of nitrogen supplement (yeast extract and DSY) coupled with the osmoprotectant (glycine) significantly promoted ethanol production from the sweet sorghum juice under the VHG conditions.

It was reported that large amounts of by-products were produced under osmotic stress or VHG conditions, and glycerol was the main by-product of ethanol fermentation [44-46]. In our study, the glycerol concentration produced during the fermentation from the juice was also slightly lower than that produced from the synthetic medium (Table 5). The lack of a marked difference in the glycerol production might be due to the fact that all conditions were carried out under the VHG fermentation at the same sugar concentration.

Figure 4. Batch ethanol fermentation in 2-L fermenter from sweet sorghum juice containing $280 \mathrm{~g} \cdot \mathrm{L}^{-1}$ of total sugar and nutrient supplements at the optimum concentrations (closed symbols) and without nutrient supplement (open symbols): pH (•०), log viable cells $(\square)$, total sugar $(\square)$ and ethanol $(\Delta \Delta)$.

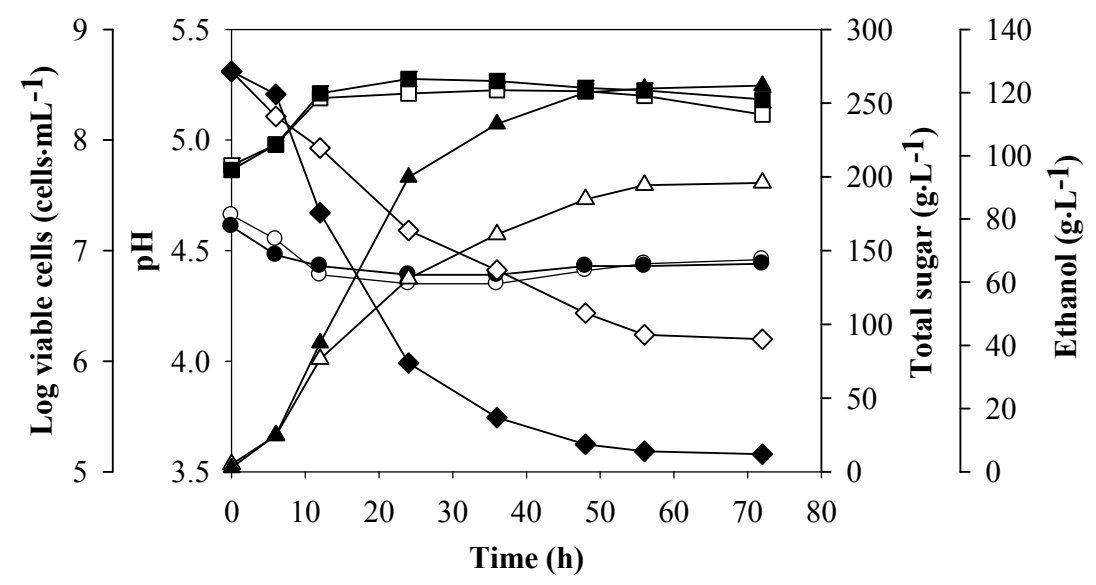

\section{Conclusions}

To achieve high ethanol production efficiency under VHG fermentation conditions, adequate amounts of essential nutrients, especially a nitrogen source, as well as osmoprotectant are required. DSY, a low-cost nitrogen source, can be used to replace some amount of higher cost nitrogen source or yeast extract. Based on this study, the optimum yeast extract, DSY and glycine concentrations supplemented in the synthetic medium under VHG ethanol fermentation were 3, 4 and $5 \mathrm{~g} \cdot \mathrm{L}^{-1}$, respectively. Sweet sorghum juice showed high potential as an energy crop for ethanol production under VHG conditions. The ethanol productivity was improved $17 \%$ when the juice supplemented with the three optimum supplement concentrations was used instead of the synthetic medium. 


\section{Acknowledgements}

This research was financially supported by the Higher Education Research Promotion and National Research University Project of Thailand through Biofuels Research Cluster of Khon Kaen University (KKU), Office of the Higher Commission Education and the Fermentation Research Center for Value Added Agricultural Products (FerVAAP), KKU, Thailand. We would like to thank Paiboon Danviruthai, Faculty of Technology, KKU for providing the NP01 strain, Beerthip Brewery (1991) Co., Ltd., Bang Baan, Phra Nakhon Sri Ayutthaya, Thailand for providing DSY and Aroonwadee Chanawong, Faculty of Associated Medical Sciences, KKU and Preekamol Klanrit, Faculty of Technology, KKU for their internal reviews of this paper and helpful suggestions.

\section{References}

1. Wildenborg, T.; Lokhorst, A. Introduction on $\mathrm{CO}_{2}$ geological storage classification of storage options. Oil Gas Sci. Technol. 2005, 60, 513-515.

2. Grahovac, J.; Dodić, J.; Jokić, A.; Dodić, S.; Popov, S. Optimization of ethanol production from thick juice: A response surface methodology approach. Fuel 2012, 93, 221-228.

3. Dodić, S.; Popov, S.; Dodić, J.; Ranković, J.; Zavargo, Z.; Mučibabić, R.J. Bioethanol production from thick juice as intermediate of sugar beet processing. Biomass Bioenergy 2009, 33, 822-827.

4. Reddy, L.V.A.; Reddy, Y.H.K.; Reddy, L.P.A.; Reddy, O.V.S. Wine production by novel yeast biocatalyst production by immobilization of volatile compounds. Process Biochem. 2006, 43, 748-752.

5. Nuanpeng, S.; Laopaiboon, L.; Srinophakun, P.; Klanrit, P.; Jaisil, P.; Laopaiboon, P. Ethanol production from sweet sorghum juice under very high gravity conditions: Batch, repeated-batch and scale up for fermentation. Electron. J. Biotechnol. 2011, 14, 1-12.

6. Khongsay, N.; Laopaiboon, L.; Jaisil, P.; Laopaiboon, P. Optimization of agitation and aeration for very high gravity ethanol fermentation from sweet sorghum juice by Saccharomyces cerevisiae using an orthogonal array design. Energies 2012, 5, 561-576.

7. Yue, G.; Yu, J.; Zhang, X.; Tan, T. The influence of nitrogen sources on ethanol production by yeast from concentrated sweet sorghum juice. Biomass Bioenergy 2012, 39, 48-52.

8. Bayrock, D.P.; Ingledew, W.M. Application of multistage continuous fermentation for production of fuel alcohol by very-high-gravity fermentation technology. J. Ind. Microbiol. Biotechnol. 2001, 27, 87-93.

9. Bai, F.W.; Chen, L.J.; Zhang, Z.; Anderson, W.A.; Moo-Young, M. Continuous ethanol production and evaluation of yeast cell lysis and viability loss under very high gravity medium conditions. J. Biotechnol. 2004, 110, 287-293.

10. Thomas, K.C.; Hynes, S.H.; Ingledew, W.M. Practical and theoretical considerations in the production of high concentration of alcohol by fermentation. Process Biochem. 1996, 31, 321-331.

11. Bvochorá, J.M.; Read, J.S.; Zvauya, R. Application of very high gravity technology to the cofermentation of sweet stem sorghum juice and sorghum grain. Ind. Crop. Prod. 2000, 11, 11-17.

12. Bai, F.W.; Anderson, W.A.; Moo-Young, M. Ethanol fermentation technologies from sugar and starch feedstocks. Biotechnol. Adv. 2008, 26, 89-105. 
13. Bafrncová, P.; Šmogrovičová, D.; Sláviková, I.; Pátková, J.; Dömény, Z. Improvement of very high gravity ethanol fermentation by media supplementation using Sacchromyces cerevisiae. Biotechnol. Lett. 1999, 21, 337-341.

14. Watanabe, M.; Tamura, K.; Magbanua, J.P.; Takano, K.; Kitamoyo, K.; Kitagaki, H.; Akao, T.; Shimoi, H. Elevated expression of genes under the control of stress response element (STRE) and Msn2p in an ethanol tolerate sake yeast Kyokai No.11. J. Biosci. Bioeng. 2007, 104, 163-170.

15. Liu, S.; Qureshi, N. How microbes tolerate ethanol and butanol. New Biotechnol. 2009, 26, 117-121.

16. Badotti, F.; Belloch, C.; Rosa, C.A.; Barrio, E.; Querol, A. Physiological and molecular characterization of Saccharomyces cerevisiae cachaça strains isolated from different geographic regions in Brazil. World J. Microbiol. Biotechnol. 2010, 26, 579-587.

17. Laopaiboon, L.; Nuanpeng, S.; Srinophakun, P.; Klanrit, P.; Laopaiboon, P. Selection of Saccharomyces cerevisiae and investigation of its performance for very high gravity ethanol fermentation. Biotechnology 2008, 7, 493-498.

18. Laopaiboon, L.; Nuanpang, S.; Srinophakun, P.; Klanrit, P.; Laopaiboon, P. Ethanol production from sweet sorghum juice using very high gravity technology: Effects of carbon and nitrogen supplementations. Bioresour. Technol. 2009, 100, 4176-4182.

19. Suwanapong, S.; Laopaiboon, L.; Jaisil, P.; Laopaiboon, P. Dried spent yeast and its hydrolysate as nitrogen supplements for batch and repeated-batch ethanol fermentation from sweet sorghum juice. Energies 2012, submitted.

20. Thomas, K.C.; Hynes, S.H.; Ingledew, W.M. Effects of particulate materials and osmoprotectants on very-high-gravity ethanolic fermentation by Saccharomyces cerevisiae. Appl. Environ. Microbiol. 1994, 60, 1519-1524.

21. Taguchi, G. System of Experimental Design; Krus International Publications: New York, NY, USA, 1990.

22. Zhu, G.H.; Ju, H.X. Determination of naproxen with solid substrate room temperature phosphorimetry based on an orthogonal array design. Anal. Chem. Acta 2004, 506, 177-181.

23. Wang, K.; Hao, J.; Wang, L.; Li, H. Phase factor sequences algorithm in partial transmit sequence. Trans. Tianjin Univ. 2009, 15, 23-26.

24. Melzoch, K.; Rychtera, M.; Hábová, V. Effect of immobilization upon the properties and behavior of Saccharomyces cerevisiae cell. J. Biotech. 1994, 32, 59-65.

25. Gao, M.T.; Hirata, M.; Toorisaka, E.; Hano, E. Study on acid-hydrolysis of spent cells for lactic acid fermentation. Biochem Eng J. 2006, 28, 87-91.

26. Park, S.H. Robust Design and Analysis for Quality Engineering; Chapman \& Hall: London, UK, 1996.

27. AOAC. Official Methods of Analysis, 16th ed.; Association of Official Analytical Chemists: Washington, DC, USA, 2005; No. 976.05, 978.10.

28. AOAC. Official Methods of Analysis, 17th ed.; Association of Official Analytical Chemists: Arlington, VA, USA, 2000; No. 934.01, 920.85, 942.05.

29. Zoecklien, B.W.; Fugelsang, K.C.; Gump, B.H.; Nury, F.S. Wine Analysis and Production; Chapman \& Hall: New York, NY, USA, 1995.

30. Mecozzi, M. Estimation of total carbohydrate amount in environmental samples by the phenol-sulphuric acid method assisted by multivariate calibration. Chemom. Intell. Lab. Syst. 2005, 79, 84-90. 
31. Deesuth, O.; Laopaiboon, P.; Jaisil, P.; Laopaiboon, L. Optimization of nitrogen and metal ions supplementation for very high gravity bioethanol fermentation from sweet sorghum juice using an orthogonal array design. Energies 2012, 5, 3178-3197.

32. Sirisantimethakom, L.; Laopaiboon, L.; Danvirutai, P.; Laopaiboon, P. Volatile compounds of a traditional Thai rice wine. Biotechnology 2008, 7, 505-513.

33. Walker, G.M. Yeast: Physiology and Biotechnology; Wiley: New York; NY, USA, 1998.

34. Nofemele, Z.; Shukla, P.; Trussler, A.; Permaul, K.; Singh, S. Improvement of ethanol production from sugarcane molasses through enhanced nutrient supplementation using Saccharomyces cerevisiae. J. Brew. Distill. 2012, 3, 29-35.

35. Stowe, R.E.; Mayer, R.P. Efficient screening of process variables. Ind. Eng. Chem. 1966, 56, 36-40.

36. Jangchud, A. Product optimization. In Statistics for Product Development and Application; Kasetsart University: Bangkok, Thailand, 2006; pp. 241-288.

37. Liu, R.; Shen, F. Impacts of main factors on bioethanol fermentation from stalk juice of sweet sorghum by immobilized Saccharomyces cerevisiae (CICC 1308). Bioresour. Technol. 2008, 99, 847-854.

38. Bely, M.; Sablayrooles, J.-M.; Barre, P. Automatic detection of assimilable nitrogen deficiencies during alcoholic fermentation in oenological conditions. J. Ferment. Bioeng. 1990, 70, 246-252.

39. O’Connor Cox, E.S.C.; Paik, J.; Ingledew, W.M. Improved ethanol yields through supplementation with excess assimilable nitrogen. J. Ind. Microbiol. Biotechnol. 1991, 8, 45-52.

40. Thomas, K.C.; Ingledew, W.M. Fuel alcohol production: Effect of free amino nitrogen on fermentation of very-high-gravity wheat mashes. Appl. Environ. Microbiol. 1990, 56, 2046-2050.

41. Schaffert, R.E. Sweet sorghum substrate for industrial alcohol. In Dendy DAV (Edited); Sorghum and Millets: Chemistry and Technology; American Association of Cereal Chemists: St. Paul, MN, USA, 1995; pp. 365-374.

42. Sree, N.K.; Sridhar, M.; Rao, L.V.; Pandey, A. Ethanol production in solid substrate fermentation using thermotolerant yeast. Process Biochem. 1999, 34, 115-119.

43. Bennett, A.S.; Anex, R.P. Production, transportation and milling costs of sweet sorghum as a feedstock for centrifuged bioethanol production in the upper Midwest. Bioresour. Technol. 2009, 100, 1595-1607.

44. Siderius, M.; Wuytswinkel, O.V.; Reijenga, K.A.; Kelder, M.; Mager, W.H. The control of intracellular glycerol in Saccharomyces cerevisiae influences osmotic stress response and resistance to increased temperature. Mol. Microbiol. 2000, 36, 1381-1390.

45. Berovič, M.; Pivec, A.; Košmerl, T.; Wondra, M.; Celan, Š. Influence of heat shock on glycerol production in alcohol fermentation. J. Biosci. Bioeng. 2007, 103, 135-139.

46. Zhang, A.; Chen, X. Improve ethanol yield through minimizing glycerol yield in ethanol fermentation of Saccharomyces cerevisiae. Chin. J. Chem. Eng. 2008, 16, 620-625.

(C) 2013 by the authors; licensee MDPI, Basel, Switzerland. This article is an open access article distributed under the terms and conditions of the Creative Commons Attribution license (http://creativecommons.org/licenses/by/3.0/). 